
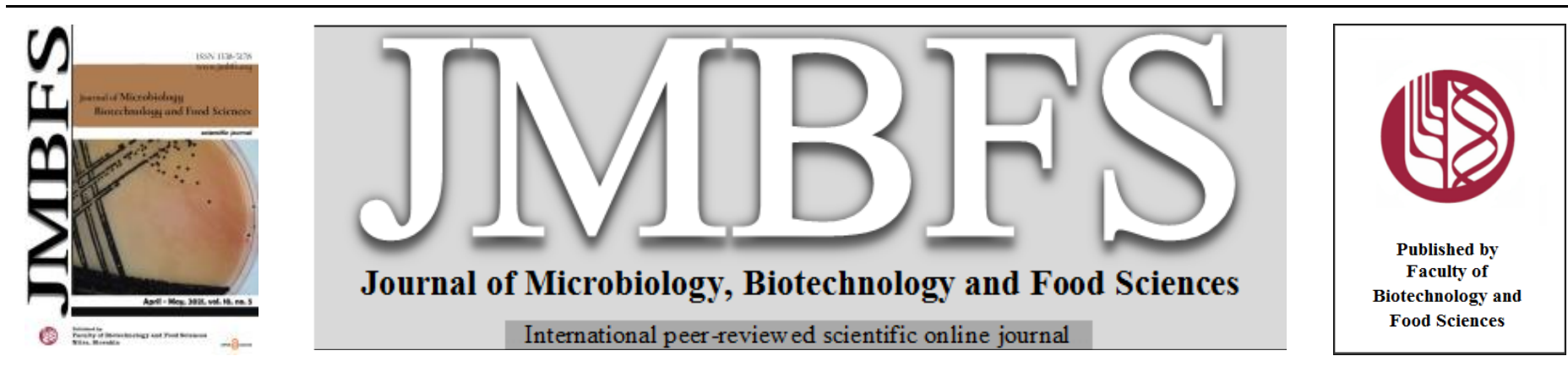

\title{
NATURAL FOOD PRESERVATION SYSTEM AS ALLYL ISOTHIOCYANATE AND EDIBLE BROWN SEAWEED LAMINARIA JAPONICA AGAINST SELECTED ANAEROBIC FOODBORNE BACTERIA: CLOSTRIDIUM PERFRINGENS AND CAMPYLOBACTER JEJUNI
}

\author{
Reham A. El Fayoumy ${ }^{* 1}$ \\ Address(es): Reham A. El Fayoumy, PhD., \\ ${ }^{1}$ Damietta University, Faculty of Science, Botany and Microbiology Department, New Damietta City, Damietta, Egypt.
}

*Corresponding author: reremado145@gmail.com

https://doi.org/10.15414/jmbfs.1923

ARTICLE INFO

Received 9. 7. 2019

Revised 28. 11. 2020

Accepted 4. 12. 2020

Published 1. 4. 2021

Regular article

OPEN $\partial_{\text {ACCESS }}$

\begin{abstract}
Allyl isothiocyanate (AITC) is basic compound in mustard essential oil and found in some other species of Brassicaceae. It has antimicrobial properties against wide range of foodborne pathogens. Its food industry use as a natural preservative is limited by its quick evaporation, taste pungency, and weak water solubility. The minimum inhibitory concentration (MIC) for AITC against the two tested bacteria; Clostridium perfringens and Campylobacter jejuni was determined by Microdilution assay, which were 0.078 and 0.039 $\mathrm{mg} / \mathrm{ml}$, respectively. According to the results of the same assay, bactericidal effect was recorded against both tested bacteria. By using vapor and solution deposition ways into Laminaria japonica de-oiled powder, the antimicrobial effect of AITC vapor was demonstrated against the selected bacteria; up to $91 \%$ of colony deactivation occurred within $72 \mathrm{~h}$ for $C$. perfringens, while $97 \%$ for $C$. jejuni, the decay behavior of both solution and vapor -deposited were parallel. At $72 \mathrm{~h}$, the de-oiled L. japonica powder was adsorbed AITC twice that of the raw powder approaching $99 \%$ theoretical maximum amount. The continued antimicrobial activity of AITC after contact proves that AITC + de oiled L. japonica powder would be used as natural system for preserve food.
\end{abstract}

Keywords: Allyl isothiocyanate; Laminaria japonica; antimicrobial effect; anaerobic foodborne bacteria; Clostridium perfringens; Campylobacter jejuni

\section{INTRODUCTION}

Managing and keep the food in ways that control food borne diseases is described as food safety. This contains some of protocols that should be applied to stop food borne diseases outbreaks. Three types of microorganisms can contaminate food which in many cases lead to death and cause public health problems: bacteria, molds, and yeasts. Yeast and molds cause spoilage of food so, they make the big economic problems in the food industry (http://www.foodsafetysite.com).

Food preservation by traditional strategies including physical preservation and chemical antimicrobial addition may lead to organoleptic changes in foods and/or the loss of its nutrients. In addition, chemicals have side effects on human health. These factors reduce consumer acceptance, needing a novel methods for food preservation, including new and natural preservatives (Tiwari et al., 2009).

Middle Eastern peoples rely on vegetables and fresh products as their main source of carbohydrates, vitamins, processed food, fermented sausages, dairy products, meat and poultry as protein. All of these can get contamination by many microorganisms, just like anaerobic Gram negative bacteria Campylobacter jejuni (https://www.who.int/news-room/fact-sheets/detail/campylobacter) and anaerobic Gram positive bacteria Clostridium perfringens (Bennett et al., 2013), which considered more dangerous on human and foodborne diseases (FBD) than aerobic one. These anaerobic bacteria don't need oxygen for growth, so it can contaminate many types of food; processed canned, fresh, and raw food. $C$. perfringens is the second microorganism responsible for causing foodborne diseases in the United States, after Salmonella typhimurium. It is Gram-positive spore-forming anaerobic rod and found in many environments (especially in the intestines of many animals and humans) (Brynestad and Granum, 2002). The areas which contaminated with human or animal fecal pollution contains the spores of this bacteria in its soil. C. perfringens is the most dangerous bacterial species that they have fatal toxins so; it causes food contamination during manufacture (Le Loir et al., 2003). C. perfringens causes perfringens disease. Campylobacter jejuni is Gram negative anaerobic bacteria, which can reach to your system via eating insufficiently cooked poultry or you eat food that has touched raw or insufficiently cooked poultry. Animals' digestive system just like chickens and cattle is the place where $C$. jejuni live. Unpasteurized milk also has Campylobacter bacteria, which the diarrhea is the main symptoms of campylobacteriosis. children and babies can get infected easily by Campylobacter than adults (https://www.webmd.com/food-recipes/food-poisoning/what-is-campylobacterinfection\#1). Both bacteria can grow in a different environmental condition such as freezing and moderate high temperatures $\left(2-45^{\circ} \mathrm{C}\right)$.

The increasing of side effects of the synthetic food preservatives has needed to use natural preservatives instead (Hyldgaard et al., 2012). In past, some spices and plants were used to keep the food preserved for long time, but at the same time, they have an organoleptic effects which they could not overcome (Han, 2013). Allyl isothiocyanate (AITC) is the basic effective compound in mustard essential oil which has bactericidal and bacteriostatic effects against many species of bacteria and also fungicidal against many types of fungi. Although in Japan now, AITC is added to food for increase its shelf life, but AITC is permitted as a food preservative due to it contains some residual chloride compounds and its strong organoleptic effect in food (Isshiki et al., 1992). The US FDA approved that AITC is a safe food additive, when set at a maximum of $25 \mathrm{mg} / \mathrm{kg} /$ day for human's body (Isshiki $\boldsymbol{e t}$ al., 1992), however, it has not been approved as a food preservative yet.

There are challenges of using AITC as antimicrobial preservative because of its physical properties, which it is highly evaporated in liquid phase. Adsorption and desorption of AITC from porous delivery solids such as powder of mustard seeds (Dai and Lim, 2014), beads of calcium alginate (Kim et al., 2008), powder of maize (Paes et al., 2011), and silica mesoporous carrier (Park and Pendleton, 2012) used to avoiding this problem. Each of these systems acted as system for increasing shelf life of food and keep it away from any contamination or spoilage. Siahaan et al. (2014) used Saccharina japonica as porous carrier system for AITC, they demonstrated that AITC has antimicrobial activity towards Salmonella Typhimurium, Escherichia coli and Bacillus cereus after desorption from the brown seaweed. Also, we used in our previous study other natural food preservative system (AITC as natural compound carried on edible seaweed L. japonica) against some Gram-positive foodborne bacteria (Bacillus subtilis, Listeria monocytogenes, and Micrococcus luteus), and we proved it was an effective system to suppressed and controlled these food borne bacteria (EI Fayoumy et al., 2017). 
This research demonstrated the antimicrobial effect of allyl isothiocyanate (AITC) on two dangerous anaerobic foodborne bacteria which make contamination easily to raw and processed food (Clostridium perfringens, and Campylobacter jejuni). So, we used this natural food preservative system consist of allyl isothiocyanate (AITC) compound which is main constituent of mustard essential oil and another carrier, edible brown seaweed, Laminaria japonica which found in the sea waters of the Middle East, Japan and other countries around the world. This natural food preservative system proved before in our other research, it can overcome the annoyable physical properties of AITC which limit its using as food preservative (El Fayoumy et al., 2017). The de-oiled powder of L. japonica was examined as a suitable carrier for AITC, with subsequent antimicrobial tests of vapor released activity after solution and vapor deposition methods against the two tested anaerobic foodborne bacteria. Siahaan et al. (2014) used two different diameters of their particle carrier in their work (900 and $500 \mu \mathrm{m}$ ), and they found that; The larger particle diameter of the delivery carrier for AITC led to greater amount of AITC adsorbed. So according to this, the current work aimed to finding a more economic process and test it antimicrobial activity in a small amount, so we used the smaller particle size (500 $\mu \mathrm{m})$ as a carrier made by vapor and solution phase AITC deposition.

\section{MATERIALS AND METHODS}

\section{Materials}

Brown seaweed L. japonica was getting from Guemil-eup, Wando-gun, South Korea. Both dimethyl sulfoxide (DMSO) and AITC were $99.9 \%$ grade. The media of the bacterial growth were Tryptose sulfite cycloserine (TSC) agar, Tryptose sulfite cycloserine (TSC) broth, Mueller Hinton broth + CSS (Campylobacter selective supplement) and Mueller Hinton agar (MHA) +CSS all were bought from Sigma Aldrich, Australia.

\section{Preparation of selective media}

Tryptose sulfite cycloserine (TSC) agar is selective media for isolation and enumeration the spores of Clostridium perfringens in food (Harmon et al., 1971). S.F.P. Agar base media (Shahidi - Ferguson Perferingens) which consist of tryptose, soya peptone, yeast extract, sodium bisulphite, ferric ammonium citrate and agar was bought from Sigma Aldrich, Australia, then suspend $42 \mathrm{gm}$ in 1 litter distilled water. Boil to dissolve the media. Sterilize by autoclaving at 15 Ibs. Pressure $\left(121^{\circ} \mathrm{C}\right)$ for $15 \mathrm{~min}$. Cool to $50{ }^{\circ} \mathrm{C}$. Add $400 \mathrm{mg}$ of rehydrated Dcycloserine (Sigma Aldrich, Australia) to 1 litter of SEP Agar base media as selective agent for $C$. perfringens growth, which appeared as black colonies. TSC broth media is the same composition but without agar. For growth Campylobacter jejuni, one vial of CSS which consist of sodium pyruvate vancomycin, cefoperazon and cycloheximide was bought from Sigma Aldrich, Australia, then added to sterilized $500 \mathrm{ml}$ of Mueller Hinton agar (MHA)(Sigma Aldrich, Australia), and the same for preparation broth Mueller Hinton media (Bolton et al., 1983).

\section{Bacterial cultures preparation}

Cultures of two tested bacterial strains Clostridium perfringens, and Campylobacter jejuni were made by streaking stocks of culture on to (TSC) agar and (MHA) +CSS media respectively inside anaerobic chamber which has oxygen removing system (Model BJPX-G-1), which A hydrogen (H2) gas mixture is circulated through a heated palladium catalyst to get rid of oxygen (O2) by forming water $(\mathrm{H} 2 \mathrm{O})$, and provided $0.25 \% \mathrm{CO}_{2}$ for $C$. perfringens, which small amount of $\mathrm{CO}_{2}$ is enough for its growth (Reilly, 1980), but provided for $C$. jejuni $10 \% \mathrm{CO} 2$ for its growth (Park, 2002). then left to grow in anaerobic incubator inside the chamber until appearance of visible colonies $\left(48 \mathrm{~h}, 37^{\circ} \mathrm{C}\right)$ for both tested bacteria. One colony of each bacteria was then picked up to start seed cultures in their selective broth media $\left(5 \mathrm{~mL}, 16 \mathrm{~h}\right.$ and $\left.37^{\circ} \mathrm{C}\right)$ anaerobically in an incubator shaker at $180 \mathrm{rpm}$ to perform next tests.

\section{Determination of MIC for AITC against the selective bacteria}

This assay aims to know the minimum inhibitory concentration (MIC) of the AITC against the tested microorganisms, representing the lowest concentration that completely inhibits the growth of microorganisms.

Stock solutions of $20 \mathrm{mg} / \mathrm{ml}$ of AITC were prepared with DMSO (20\%) as a solvent. 96 wells sterilized plate was used for the assay. To each well on the plate, $100 \mu \mathrm{l}$ of selective media broth for each tested bacterium was added in the first row, $100 \mu \mathrm{l}$ of the stock solution was added. Subsequent rows were filled by transferring $100 \mu \mathrm{l}$ by serial dilution resulting in AITC concentration from 10 to $0.0097 \mathrm{mg} / \mathrm{ml}$ across the 96-well microtiter plates. DMSO (20\%)-media broth with no tested compound acted as a control in the wells of the last row of the plate. Then inoculated each well with $100 \mu$ inoculum of each tested bacterium, using a 16-h culture adjusted by the McFarland standard. Additional dilution was made with the selective broth media for each bacterium to make approximately $10^{6}$ CFU.ml ${ }^{-1}$. The total volume of each well in the plate, $200 \mu$, was then incubated anaerobically at $37^{\circ} \mathrm{C}, 16 \mathrm{~h}$ at $150 \mathrm{rpm}$ agitation for both bacteria Experiments were carried out triplicate. By HT Multi-detection Microplate Reader (Bio-Tek, UK) at $540 \mathrm{~nm}$, we compared the absorbance values before and after incubation, so the inhibition of bacterial growth was recorded. The MIC is defined as the lowest concentration of the antimicrobial compound make inhibition for any visible growth (Andrews, 2001).

\section{Type of Antimicrobial effect of AITC against the tested bacteria}

This test was performed to determine the type of effect AITC had against the tested bacteria, i.e., if it was bacteriostatic or bactericidal.

This assay depended on the results of the previous micro-dilution assays. The definitions used in this work were those established by others (Smith-Palmer and Fyfe, 1998). Aliquots of $15 \mu \mathrm{l}$ from the wells that the bacteria inhibited and/or failed to grow were plated onto the selective media agar plates for each tested bacterium, then the plates were incubated for $24 \mathrm{~h}$ at $37^{\circ} \mathrm{C}$ anaerobically. Three times of each micro assay were performed.

Food preservative system consists of AITC and L. japonica as edible carrier

\section{Powder of $L$. japonica preparation}

Fresh de oiled and raw L. japonica samples were used as medium carriers for AITC and were prepared according to El Fayoumy et al. (2017). Supercritical carbon dioxide $\left(\mathrm{SC}-\mathrm{CO}_{2}\right)$ used for extraction the lipid content of $L$. japonica $(\mathbf{E}$ Fayoumy et al., 2017).

\section{AITC adsorption by L. japonica powder}

The adsorption of AITC by L. japonica was performed according to El Fayoumy et al. (2017), which used vapor and solution adsorption. For both ways, the amount of AITC loaded was calculated by recording wight increasing of the samples with time $(4,8,12,24,48$, and $72 \mathrm{~h})$.

\section{AITC antimicrobial assay}

\section{Initial growth determination for bacterial suspensions}

The growth of Clostridium perfringens, and Campylobacter jejuni were occurred anaerobically on selective liquid media (15 mL) (TSC) agar and (MHA) +CSS media respectively with shaking $(200 \mathrm{rpm})$ for $18 \mathrm{~h}$ at $37^{\circ} \mathrm{C}$. These two cultures acted as inoculum. the optical density of the overnight liquid samples was measured at $540 \mathrm{~nm}$ by using spectrophotometer (Fisher Scientific). Commonly the bacterial turbidity measured in the range of $(420 \mathrm{~nm}-660 \mathrm{~nm})$, because the bacterial cells in this range of UV will not get affected or dead, which the UV causes mutations in the bacterial cell and destroying its genes. At wavelength $420 \mathrm{~nm}$, spectrophotometer gave blue ray and used if the media was colorless, spectrophotometer gave green ray at $540 \mathrm{~nm}$ and used if the media was yellow like media used in this research, but at $600 \mathrm{~nm}$ gave orange ray and used if the media was brown (Gunasekaran, 2007). The absorbance at $\mathrm{OD}_{540}$ was increased when the culture concentration increased. The microorganism's growth reached to the required concentration by these absorbances. a 0.5 McFarland standard used to make same concentration of the bacterial growth. The same initial bacterial concentration was made by dilution the growth culture of each tested bacteria, which make it to $10^{6} \mathrm{CFU} / \mathrm{mL} .10^{-1}$ to $10^{-8}$ serial dilution of each tested bacterial culture $(1 \mathrm{~mL})$ were made by suspending them in a sterile saline solution to make $10 \% \mathrm{v} / \mathrm{v}$ for each dilution factor. Samples $(1 \mathrm{~mL})$ of each tested bacterium were then spread on their selective media agar plates for each one three times for calculating the means according to their dilution factors. Then we incubated them for $72 \mathrm{~h}$ at $37{ }^{\circ} \mathrm{C}$ anaerobically. For each colony, initial cell counts were made.

\section{Antimicrobial assay of released AITC vapor}

Three vacuum desiccators $\left(10 \mathrm{~L}\right.$ at $\left.25^{\circ} \mathrm{C}\right)$ were prepared as containers for each tested bacterium. The first vacuum desiccator contained AITC loaded on $L$. japonica via vapor adsorption, the second one, AITC loaded on L. japonica via solution adsorption, and the last, served as a control, which there is no AITC or L. japonica. Glass tube containing $(2 \mathrm{~mL})$ overnight-grown selected bacteria cultures was put in each desiccator. Samples tubes were taken periodically after $4,8,12,24,48$, and $72 \mathrm{~h}$. On removal, the samples were diluted and ( $1 \mathrm{~mL}$ ) was inoculated on the selective media agar plates for each bacterium to determine the effect of exposure to AITC vapor (released from L. japonica carrier) on further microorganism growth. Then, we incubated these plates at $37{ }^{\circ} \mathrm{C}$ anaerobically for $72 \mathrm{~h}$. Any further growth, determined as a colony count on the spread plate was adjusted for its corresponding dilution factor. Three replicates of each assay were made. 


\section{Statistical analysis}

All required measurements were carried out in triplicate and the results were calculated as mean \pm standard deviation, in addition to statistical analysis using the one-way (ANOVA), the mean difference is significant at $\mathrm{P}<0.05$ level by using SPSS version 22 .

\section{RESULTS AND DISCUSSION}

AITC antimicrobial activity against two selected anaerobic foodborne bacteria, Clostridium perfringens, and Campylobacter jejuni was proved in the discussion below. These bacteria have been found as pollutants in some processed and raw food consumed all over the world. The antimicrobial compound (AITC) inhibit, and destroys many bacteria and fungi (Park and Pendleton, 2012). Since, an edible natural carrier was being used in our previous paper against some aerobic gram positive foodborne bacteria, and it didn't have any reducing effect on AITC antimicrobial activity (EI Fayoumy $\boldsymbol{e t}$ al., 2017), but it was necessary to establish if this carrier has any reducing effects on AITC antimicrobial activity towards the selected anaerobic foodborne microbes in the present study.

\section{Determination of MIC for AITC against the selective bacteria}

This assay for calculating MIC (minimum inhibition concentration) of AITC for each bacterial strain, and it is known as the minimum concentration that completely prevent the bacterial growth (Andrews, 2001). MIC for AITC against C. jejuni $(0.039 \mathrm{mg} / \mathrm{ml})$ was lower than MIC of AITC against $C$. perfringens $(0.078 \mathrm{mg} / \mathrm{ml})$, that means, $C$. jejuni is more sensitive towards AITC than $C$. perfringens, and this because of the ability of Gram +ve bacteria $C$. perfringens to form endospore in the hard stress conditions, which gave it more resistant towards AITC and other antimicrobial compounds than Gram -ve bacteria. In addition, Gram +ve bacterial cell membrane can be as much as 20 -fold thicker than the cell membrane of Gram -ve bacteria, also Gram +ve bacteria have a greater volume of peptidoglycan, which makes the thick outer covering and give more protection than Gram -ve one (http://info.achs.edu/blog/gram-positivegram-negative-bacteria)Table 1 .

Lu et al. (2016) demonstrated that the minimum inhibition concentration (MIC) of AITC against foodborne microbes was at range 10 to $100 \mu \mathrm{g} / \mathrm{ml}$. Also Shofran et al. (1998) found in their research that MICs of AITC were $(0.05$ to 1 $\mathrm{mg} / \mathrm{ml}$ ) in broth culture for bacterial species and that is very close to our results.

Table 1 MIC for AITC against each tested bacterium in the microdilution assay

Bacteria $\quad \mathrm{MIC}^{\mathrm{a}} \pm \mathrm{SE}$

$\begin{array}{lc}\text { Clostridium perfringens } & 0.078 \mathrm{mg} / \mathrm{ml} \pm 1 \\ \text { Campylobacter jejuni } & 0.039 \mathrm{mg} / \mathrm{ml} \pm 1.2\end{array}$

${ }^{\mathrm{a}}$ Values are the mean and standard error (SE) of three replicate trials.

\section{Type of the Antimicrobial effect of AITC against the tested bacteria}

AITC activity showed a bactericidal effect against both tested bacteria $C$. perfringens and $C$. jejuni. When Lu et al. (2016) used Wasabi essential oil in their research (which AITC is the main effective compound), displayed higher bactericidal activity against many tested foodborne bacteria. AITC showed a great bactericidal effect toward foodborne microbes on food products (Lin et al. 2000b). Lin et al. (2000a) demonstrated that the bactericidal effect of AITC because of its damage to the cell membrane of the bacteria which caused leakage of the components outside the cells.

\section{Food preservative system consists of AITC and $L$. japonica as edible carrier}

Park and Pendleton (2012) showed that, the desorption of antimicrobial compound from a porous materials and controlling release of this antimicrobia agent for the inhibition activity occurred via two consecutive processes; first: beginning burst of the antimicrobial compounds to make a high concentration in small time, and second: a continuous, but slower rate of desorption to keep a good concentration for the antimicrobial activity of released materials. In our previous research, we used $L$. japonica as an edible carrier, so there are not any bad effects if touched or contacted with the food. It is widely existing in large amount on the sides of marine waters of the Middle East countries, so it can be harvested easily, cheaply and legally (EL Fayoumy et al., 2017). After we proved the success of this natural preservative system against some Grampositive foodborne bacteria (EL Fayoumy et al., 2017), in this work, we used the same natural system but against other species of anaerobic foodborne bacteria Siahaan et al. (2014) which used other type of seaweeds as carrier for AITC, proved vai Fourier transform infrared red spectroscopy (FTIR) measurements that, the antimicrobial activity of AITC was not reduced or get affected because of its contact with the seaweed surface, and that is due to the interactions between AITC and the seaweed were physically only with no chemical interactions occurred, which can cause any changes in the AITC chemical structure, so no effect occurred on AITC's antimicrobial effect.

\section{AITC adsorption by L. japonica powder}

The profiles of time-dependent adsorption for AITC onto de-oiled and raw $L$. japonica powder by vapor and solution depositions were obtained in our previous study against some Gram positive foodborne bacteria (El Fayoumy et al., 2017), which showed that de-oiled L. japonica samples adsorbed AITC more than the raw samples. El Fayoumy et al. (2017) demonstrated that, the maximum amoun adsorbed at $72 \mathrm{~h}$ by the de-oiled powder was approximately twice that of the raw powder, approaching $99 \%$ theoretical maximum. This difference was back to that AITC is controlled and restricted to diffuse into the cells containing lipids, because of lipids' hydrophobic nature, which providing weak water-lipid interfacial transfer. (El Fayoumy et al., 2017; Siahaan et al., 2014).

\section{Antimicrobial assay of released AITC vapor}

SPSS analysis reveals that high significant effect $(\mathrm{P}<0.05)$ of the exposure time to the AITC vapor released from $L$. japonica powder on the count reduction of the selective bacterial cell. When AITC adsorbed via silica (Park and Pendleton, 2012), S. japonica (Siahaan et al., 2014) surfaces, and de-oiled $L$. japonica powder (El Fayoumy et al., 2017), it was only by dispersion forces, which no evidence for any chemical reactions between AITC and L. japonica, So there is no any changes in AITC's composition and according to this, the release of AITC vapor provided an antimicrobial atmosphere. El Fayoumy et al. (2017) studied before the antimicrobial effect of AITC desorption from L. japonica powder against some Gram-positive pathogenic bacteria, in this study, we will test against two dangerous anaerobic foodborne bacteria (Clostridium perfringens and Campylobacter jejuni). Data of these experiments are spread in Fig. 1. The antimicrobial effect was demonstrated by two different ways; vapor and solution loaded L. japonica powders and a control system without AITC or L. japonica powder. El Fayoumy et al. (2017) compared the deactivation curves by making the count reduction of bacteria with time, $c(t)$, and the initial count, $c_{0}$, with time, $t$. Fig. 1 show that the mean values and their standard deviation (SD). The shape of each curve in Fig. 1 proves that the decay behavior of vapor loaded systems is paralleling with the solution loaded systems. The control systems without AITC or $L$. japonica stayed a constant and same relative bacterial count. The beginning burst in AITC released at the first 12 hours led to 50-59\% reduction in both tested bacteria. After $24 \mathrm{~h}$ exposure, $81 \%$ of anaerobic gram -ve bacteria $(C$. jejuni) was inhibited, but just $69 \%$ only of anaerobic gram +ve bacteria $(C$. perfringens) was inhibited. Exposure up to $72 \mathrm{~h}$ led to $97 \%$ total reduction of C. jejuni and $91 \%$ of $C$. perfringens. The data of this system was agreed with AITC vapor deposited from silica (Park and Pendleton, 2012). C. jejuni was more sensitive than $C$. perfringens. These findings were compatible with our MICs data, which proved that Gram +ve bacteria are more survival to AITC than Gram -ve bacteria. Finally, we concluded that, there were parallelism between the decay behavior of AITC vapor toward the microbial growth for both vapor and solution loaded, and the different in the inhibition of the both tested bacteria couldn't be noticeable and very small (Fig.1), these results are agreed with our previous results (EI Fayoumy et al., 2017), so the using of vapor as loading way would be more cheaper and safety, in addition to more economic than solution deposition. (Fig. 1).

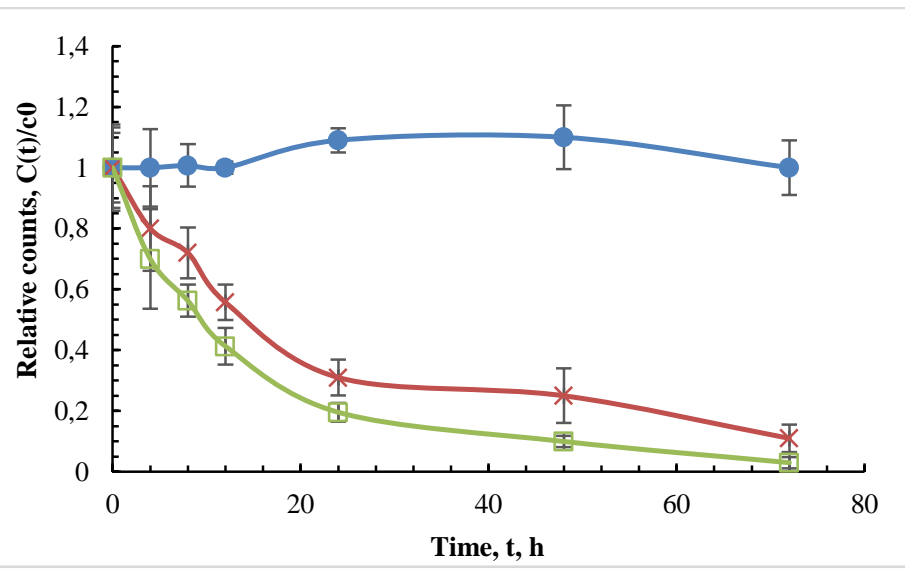




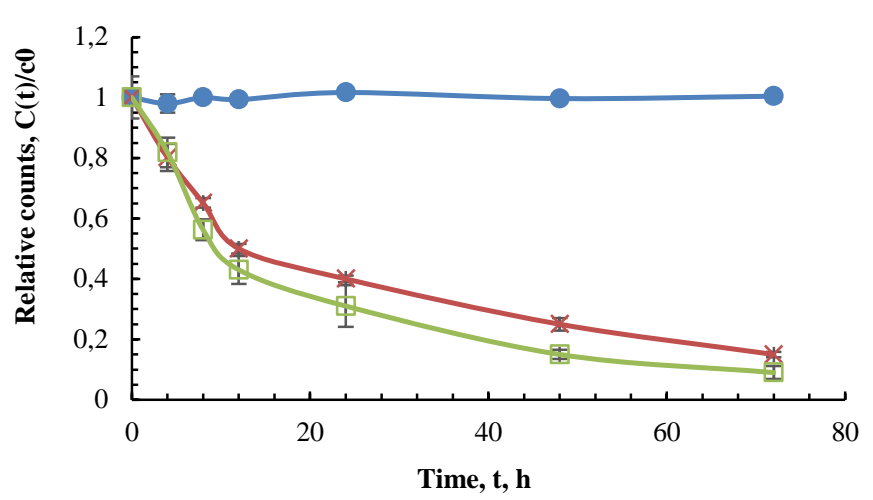

Figure 1 Antimicrobial activity of AITC vapor on the two tested bacteria released from de-oiled powder $L$. japonica, by vapor $(\times)$, solution $(\square)$ adsorption and control (-), (A) For Campylobacter jejuni and (B) for Clostridium perfringens

\section{CONCLUSION}

In the present work, we demonstrated that AITC has a bactericidal effect against anaerobic foodborne bacteria Clostridium perfringens and Campylobacter jejuni. The de-oiled L. japonica powder adsorbs AITC more than the raw powder, which produces a suitable antimicrobial atmosphere inhibiting the growth of these two pathogenic bacteria. Since the decay behavior of AITC vapor which loading via vapor- and solution-deposition were parallel, and the different in the inhibition of all tested bacteria couldn't be noticeable and very small between the both loading ways, so the vapor loading way would be better to use in this system than solution one according to the healthy and economic viewpoints. De-oiled $L$. japonica powder would be safe, natural edible carrier for the antimicrobial agents to prevent the food contamination or food spoilage by different range of foodborne aerobic and anaerobic bacteria, so it can be used as natural food preservation system enhancing safety and security of food during its transportation and storage processes.

Acknowledgement: Author thanks the office of Egyptian Mission for the financial support, the University of South Australia and Faculty of Science at Damietta University.

\section{REFERENCES}

Andrews, J. M. (2001). Determination of minimum inhibitory concentrations. Journal of Antimicrobial Chemotherapy, 48(1), 5-16. https://doi.org/10.1093/jac/48.suppl_1.5

Bennett, S. D., Walsh, K. A., \& Gould, L. H. (2013). Foodborne disease outbreaks caused by Bacillus cereus, Clostridium perfringens, and Staphylococcus aureus. Clin Infect Dis., 57(3),425-33. https://doi.org/10.1093/cid/cit244

Bolton, F., Coates, D., \& Hinchliffe, P. (1983). Comparison of selective media for isolation of Campylobacter jejuni/coli. Journal of Clinical Pathology, 36, 7883. https://doi.org/10.1136/jep.36.1.78

Brynestad, S., \& Granum, P. E. (2002). Clostridium perfringens and food borne infections. Int. J. Food Microbiol., 74, 195-202. https://doi.org/10.1016/S0168 1605(01)00680-8

Dai, R., \& Lim, L. T. (2014). Release of Allyl Isothiocyanate from Mustard Seed Meal Powder. Journal of Food Science, 79, 47-53. https://doi.org/10.1111/17503841.12322

EL Fayoumy, R. A., Pendleton, P., El-FallaL, A. A., Abou-Dobara, M. I., \& ElSayed, A. K. (2017). Allyl Isothiocyanate Release from Edible Laminaria japonica for Time-Dependent Growth Deactivation of Foodborne Pathogens: I: Micrococcus luteus, Bacillus subtilis, and Listeria monocytogenes. Food and Bioprocess Technology, 10(8), 1562-1573. https://doi.org/10.1007/s11947-0171925-0

Gunasekaran, P. (2007). Laboratory Manual in Microbiology. New Age International, 152.

Han, J. H. (2013). Innovations in Food Packaging (2nd ed.). San Diego: Academic press (Elsevier), 369-390. https://doi.org/10.1002/pts.811

Harmon, S. M., Kautter, D. A., \& Peeler, J. T. (1971). Improved Medium for Enumeration of Clostridium perfringens. Applied Microbiology, 22(4), 688-692. https://doi.org/10.1128/aem.22.4.688-692.1971

Hyldgaard, M., Mygind, T., \& Meyer, R. L. (2012). Essential oils in food preservation: mode of action, synergies, and interactions with food matrix components. Frontiers in Microbiology, $\quad 3, \quad 12$ https://doi.org/10.3389/fmicb.2012.00012

http://www.foodsafetysite.com.

https://www.who.int/news-room/fact-sheets/detail/campylobacter https://www.webmd.com/food-recipes/food-poisoning/what-is-campylobacterinfection\#1 http://info.achs.edu/blog/gram-positive-gram-negative-bacteria

Isshiki, K., Tokuoka, K., Mori, R., \& Chiba, S. (1992). Preliminary examination of allyl isothiocyanate vapor for food preservation. Bioscience, Biotechnology and Biochemistry, 56, 1476-1477. https://doi.org/10.1271/bbb.56.1476

Kim, W. T., Chung, H., Shin, I. S., Yam, K. L., \& Chung, D. (2008) Characterization of calcium alginate and chitosan-treated calcium alginate ge beads entrapping allyl isothiocyanate. Carbohydrate Polymers, 71, 566-573 https://doi.org/10.1016/j.carbpol.2007.06.028

Le Loir, Y., Baron, F., \& Gautier, M. (2003). Staphylococcus aureus and food poisoning. Genet. Mol. Res., 2 (1), 63-76.

Lin, C. M., Preston, J. F., \& Wei, C. I. (2000a). Antibacterial mechanism of ally isothiocyanate. Journal of Food Protection, 63,727-734 https://doi.org/10.4315/0362-028X-63.6.727

Lin, C. M., Preston, J. F., \& Wei, C.I. (2000b). Bactericidal Activity of IsothiocyanateAgainst Pathogens on Fresh Produce. Journal of Food Protection, 63 (1),2530. https://doi.org/10.4315/0362-028X-63.1.25

Lu, Z., Dockery, C. R., Crosby, M., Chavarria, K., Patterson, B., \& Giedd, M. (2016). Antibacterial Activities of Wasabi against Escherichia coli O157:H7 and

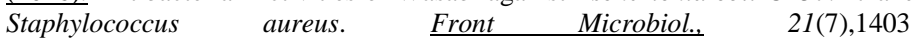
https://doi.org/10.3389/fmicb.2016.01403

Paes, J. L., Faroni, L. R. A., Martins, M. A., Dhingra, O. D., \& Silva, T. A. (2011). Diffusion and sorption of allyl isothiocyanate in the process of fumigation of maize. Revista Brasileira de Engenharia Agrícola e Ambiental, 15, 296-301. https://doi.org/10.1590/S1415-43662011000300011

Park, S. F. (2002). The physiology of Campylobacter species and its relevance to their role as food borne pathogens. Int. J. Food Microbiol., 74(3), 177-188 https://doi.org/10.1016/s0168-1605(01)00678-X

Park, S. Y., \& Pendleton, P. (2012). Mesoporous silica SBA-15 for natural $\begin{array}{llll}\text { antimicrobial delivery. } & \text { Powder } & \text { Technology, } & \text { 223,77-82 }\end{array}$ https://doi.org/10.1016/i.powtec.2011.08.020

Reilly, S. (1980). The carbon dioxide requirements of anaerobic bacteria. J Med Microbiol., 13(4), 573-579. http://doi:10.1099/00222615-13-4-573

Shofran, B. G., Purrington, S. T., Breidt, F., \& Fleming, H. P. (1998) Antimicrobial properties of sinigrin and its hydrolysis products. Journal of food science, 63(4), 621-624. https://doi.org/10.1111/j.1365-2621.1998.tb15798.x

Siahaan, E. A., Pendleton, P., Woo, H. C., \& Chun, B. S. (2014). Brown seaweed (Saccharina japonica) as an edible natural delivery matrix for allyl isothiocyanate inhibiting food-borne bacteria. Food Chemistry, 152, 11-17. https://doi.org/10.1016/j.foodchem.2013.11.116

Smith-Palmer, S., \& Fyfe. (1998). Antimicrobial properties of plant essential oils and essences against five important food-borne pathogens. Letters in Applied Microbiology, 26(2), 118-122. https://doi.org/10.1046/j.1472-765X.1998.00303.x Tiwari, B. K., Valdramidis, V. P., O' Donnell, C. P., Muthukumarappan, K. Bourke, P., \& Cullen, P. J. (2009). Applicationof Natural Antimicrobials for Food Preservation. Journal of Agricultural and Food Chemistry, 57, 5987-6000. https://doi.org/10.1021/jf900668n 